Original Research Paper

\title{
Production and Characterization of Hydrocarbon Degrading Peroxidase from Rhizopus and Saccharomyces Species
}

\author{
${ }^{1,2}$ Ferdinand U. Paschaline, ${ }^{2}$ Onyeocha O. Ignatius, ${ }^{2}$ Ezeji E. Uchechukwu, \\ ${ }^{2}$ Ukwandu C.D. Nnamdi, ${ }^{3,4}$ Engwa A. Godwill and ${ }^{5}$ Oparaji E. Henry \\ ${ }^{I}$ Bio-Resources Development Center Abagana, National Biotechnology Development Agency (NABDA), Abuja, Nigeria \\ ${ }^{2}$ Department of Biotechnology, Federal University of Technology, Owerri, Nigeria \\ ${ }^{3}$ Biotechnology Programme, Department of Biology/Microbiology/Biotechnology, \\ Alex Ekwueme Federal University Ndufu-Alike, Ebonyi State Nigeria \\ ${ }^{4}$ Biochemistry programme, Department of Chemical Sciences, Godfrey Okoye University, \\ P.M.B 01014 Thinkers Corner, Enugu Nigeria \\ ${ }^{5}$ Department of Biochemistry, University of Nigeria, Nsukka, Nigeria
}

Article history

Received: 28-09-2019

Revised: 01-11-2019

Accepted: 05-12-2019

Corresponding Author: Ferdinand U. Paschaline Bio-Resources Development Center Abagana, National Biotechnology Development Agency (NABDA), Abuja,

Nigeria. Department of Biotechnology, Federal University of Technology, Owerri, Nigeria.

Tel: +2348060871459

Email: pascysweet@gmail.com

\begin{abstract}
The production, characterization and partial purification of hydrocarbon degrading peroxidase from di-culture of Rhizopus and Saccharomyces species was assessed. The fungi were isolated from hydrocarbon polluted soil and identified using standard microbiological and biochemical techniques. Fermentation was carried out for enzyme production and the extracellular extract was precipitated with $50 \%$ ammonium sulphate salts and further purified by gel filtrationlusing sephadex G100 gel and by dialysis. The enzyme activity and stability was assayed against varied $\mathrm{pH}$ and temperature. Four genera of fungi which included Saccharomyces, Penicillium, Rhizopus and Aspergillus species were isolated from the crude oil polluted soil of which Saccharomyces sp. and Rhizopus sp. produced peroxidase. Maximum enzyme production occurred on day 8. The enzyme activity was optimum at a $\mathrm{pH}$ of 4.5 and temperature of $50^{\circ} \mathrm{C}$. The $\mathrm{Km}$ and $\mathrm{V}_{\text {MAX }}$ were $1.8 \mathrm{mg} / \mathrm{mL}$ and $20.3 \mu \mathrm{mol} / \mathrm{min}$ respectively, against the $5 \mathrm{mM}$ of O-dianisidine substrate. Stability studies showed that the peroxidase was stable in the presence of $\mathrm{Ca}^{2+}, \mathrm{Mg}^{2+}$ and $\mathrm{Co}^{2+}$, with $\mathrm{Ca}^{2+}$ showing the best stability. In conclusion, peroxidase was partially purified from di-culture of Saccharomyces and Rhizopus species isolated from crude oil polluted soil. The presence of this enzyme in crude oil polluted soil may suggest its implication in the degradation of crude oil. Further studies need to be done to assess the potential of this enzyme in the degradation of crude oil.
\end{abstract}

Keywords: Peroxidase, Rhizopus sp., Saccharomyces sp., pH and Temperature Stability

\section{Introduction}

Microorganisms have been considered as treasure of useful enzymes. Microorganisms possess specific enzyme systems that enable them to degrade and utilize hydrocarbons as their sole carbon and energy sources (Al-sayegh et al., 2016). Fungal isolates from polluted soil are able to use hydrocarbon present in that area as substrates for growth. This can be achieved probably by releasing extracellular enzymes and acids which are capable of breaking down the recalcitrant hydrocarbon molecules into simpler forms or products that can be absorbed for the growth and nutrition of fungi. Enzymes are biological catalysts that facilitate the transformation of substrates into products by providing favorable conditions that lower the activation energy of the reaction. The functional diversity of these enzymes and their specificity in reactions has led to increased interest in the production process and field application studies of enzymes (Nair and Jaayachandran, 2017). Peroxidases are oxidative enzymes with the capacity to oxidize several recalcitrant compounds. They are characterized by various biotechnological potentials spanning different industries including textiles, paper and pulp, chemicals, water and cosmetics etc. (Draelos, 2015; Taboada-Puig et al., 2015). They are ubiquitous enzymes that catalyse the oxidation of lignin and other phenolic compounds at the expense of hydrogen peroxide $\left(\mathrm{H}_{2} \mathrm{O}_{2}\right)$ in the presence of a mediator. These peroxidases can be 
heam or non-heam proteins (Chandrakant and Shwetha, 2011). The super-family of haem peroxidases from plants, fungi and bacteria are a group of enzymes that utilize hydrogen peroxide to oxidize a second (reducing) substrate, often an aromatic oxygen donor. Peroxidases catalyze various oxidative reactions in which electrons are transferred to peroxide species (often $\mathrm{H}_{2} \mathrm{O}_{2}$ ) and substrate molecules are oxidized. These enzymes have been found in all living organisms, involved in a variety of biological processes (Krainer and Glieder, 2015).

The detoxification of toxic organic compounds by various bacteria and fungi through oxidative coupling is mediated by oxidoreductases such as peroxidase. During such oxidation-reduction reactions, the contaminants are reduced to harmless or less harmful compounds. Hamid et al. (2016) reported in his review, that peroxidase are involved in the manufacturing of many aromatic complexes, elimination of phenolics complexes from waste water and peroxides from foods, beverage and industrial wastes. However, its isolated form, peroxidases are among the most useful enzymes in biotechnology, since several industrial processes can be performed by this kind of enzyme, such as soil detoxification and bioremediation of waste waters contaminated with phenols, cresols and chlorinated phenols (Pinto et al., 2015).

Various studies have shown that peroxidases from various sources especially microbial sources have remarkable properties in the degradation of varying concentration of crude oil (Ehiosun and Usman, 2018; Feltrin et al., 2017a; 2017b; Neelam and Shamsher, 2013) and detoxification of polluted environment based on their ability to catalyze the reduction of peroxides and the oxidation of a variety of organic and inorganic compounds. However, little is known on the characteristics of peroxidase produced from fungi species especially from hydrocarbon populated soils. This study was aimed to produce, purify and characterize peroxidase isolated from fungi species obtained from crude oil polluted soil.

\section{Materials and Methods}

\section{Sampling of the Crude Oil Spilled Site}

Soil samples were collected from crude oil contaminated soil around crude effluent disposal of Onne, Eleme Local Government Area (LGA), River State Nigeria. They were put into a clean aseptic container and transferred to the laboratory.

\section{Isolation and Identification of Rhizopus and Saccharomyces Spp. from the Crude Oil Polluted Soil}

Fungal isolates from crude oil contaminated soil were obtained according to the method described by Ezeonu et al. (2013). Serial dilution of soil sample was done and inoculated on Sabaround Dextrose Agar (SDA) media prepared according to the manufacturer's description. The inoculation plates were incubated at $30^{\circ} \mathrm{C}$ for $3-4$ days for colony growth. Colonies of different hydrocarbon utilizing fungi and hydrocarbon degrading fungi were randomly picked and pure isolates were obtained following repeated sub-culturing on SDA. The spores of the isolated fungus were harvested and, aseptically transferred to the SDA slants and incubated at $30^{\circ} \mathrm{C}$ for 4 days. The three day old pure cultures were morphologically examined and identified by microscopy according to the method of Ezeonu et al. (2013) and the features and micrographs were related to "Atlas of mycology" by Barnett and Hunter (1972). The fungal isolates were further identified and characterized using biochemical techniques as described by Cappuccino and Sherman (2004) with some modifications. The total heterotrophic biomass from both the nutrient media and the mineral salt agar was counted from the grown media plate as follow:

Colony forming unit per gram $(\mathrm{CFU} / \mathrm{g})=$ colony observed $\mathrm{x}$ dilution factor $\times$ volume of inoculum

\section{Production of Peroxidase from the Isolates}

A wire loopful of the inoculum was incubated for 3 days at room temperature in a basal mineral medium supplemented with O-dianisidine (standard substrate) prepared in 3\% methanol and $0.2 \mathrm{~m}$ of phosphate buffer (pH 6.0). Peroxidase was produced from the di-culture of fungal isolates using submerged fermentation technique according to Ezeonu et al. (2013). Hundred mililiter (100 $\mathrm{mL}$ ) of sterile culture medium optimized for hydrocarbon degrading peroxidase with various optimized nutrients $(2 \mathrm{~g}$ of $\mathrm{C}_{6} \mathrm{H}_{12} \mathrm{O}_{6}, 0.4 \mathrm{~g}$ of $\mathrm{CaCO}_{3}, 0.5 \mathrm{~g} \mathrm{FeSO}_{4}, 0.1 \mathrm{~g} \mathrm{AgNO}_{3}$ ) at favorable physical conditions (incubation temperature, (25$\left.\left.40^{\circ} \mathrm{C}\right), \mathrm{pH}(3-5)\right)$ was used for the enzyme production in a $250 \mathrm{~mL}$ Erlenmayer sterile flask. The flask was stoppered with aluminum foil and autoclaved at $121^{\circ} \mathrm{C}$ for $15 \mathrm{~min}$. Two discs of the respective fungal isolates were added in the medium using a cork borer of diameter $10 \mathrm{~mm}$ and the culture was incubated for 14 days at $30^{\circ} \mathrm{C}$. Each day, the filtrate was assayed for peroxidase activity and extracellular protein concentration. The day of peak activity of the peroxidase was chosen for mass production of the enzyme from the respective fungal isolates.

\section{Enzyme Assay}

The supernatant was collected and the mixture was filtered using Whatman No. 1 filter paper. The filtrate was centrifuged at $3500 \mathrm{rpm}$ for $15 \mathrm{~min}$ and supernatant was considered as the crude enzyme. Peroxidase activity was assayed using the method of (Mclellan and Robinson, 1987; Eze et al., 2010). The change in absorbance at $460 \mathrm{~nm}$ due to the oxidation of odianisidine in the presence of hydrogen peroxide and 
enzyme extract at $30^{\circ} \mathrm{C}$ was determined using Jenway 6405 UV/VIS Spectrophotometer. The standard assay solution contained $0.3 \mathrm{~mL}$ of $0.1 \%$ o-dianisidine, $0.2 \mathrm{~mL}$ of hydrogen peroxidase, $2.4 \mathrm{~mL}$ of sodium phosphate buffer $\mathrm{pH} 6.5$ and $0.1 \mathrm{~mL}$ of enzyme extract in total of 3.0 $\mathrm{mL}$. One unit of enzyme activity was defined as the amount of enzyme that gave an absorbance change. $=0.1 / \mathrm{min}$ at $30^{\circ} \mathrm{C}$. The readings were taken every $30 \mathrm{~s}$ for $5 \mathrm{~min}$.

Protein concentration of the crude extract was quantified at $750 \mathrm{~nm}$ according to the method of Lowry et al. (1951) using Bovine Serum Albumin (BSA) as standard.

\section{Partial Purification of the Crude Extract}

The crude extract was purified following three fold purification method according to Ertan et al. (2012)

\section{Ammonium Sulphate Precipitation}

Peroxidase was precipitated by gently stirring of the crude enzyme with $20-90 \%$ saturation of solid ammonium sulphate $\left(\left(\mathrm{NH}_{4}\right)_{2} \mathrm{SO}_{4}\right)$ with increasing concentration of $10 \%$ in each tube. The ammonium sulphate crude enzyme solutions were allowed to stand at cold temperature of $4^{\circ} \mathrm{C}$ for $30 \mathrm{~h}$ till the supernatant could be gently decanted off. The test tubes were centrifuged at $3500 \mathrm{rpm}$ for $20 \mathrm{~min}$. Precipitates from the individual percentage ammonium sulphate saturations were re-dissolved respectively in equal volumes of $0.1 \mathrm{M}$ sodium phosphate buffer $\mathrm{pH}$ 6.5. Peroxidase activity of the precipitates was assayed to determine the percentage ammonium sulphate saturation that precipitated enzyme with maximum activity. To the remaining volume of the enzyme extract, 75.52 $\mathrm{g}$ of $\left(\mathrm{NH}_{4}\right)_{2} \mathrm{SO}_{4}$ was added slowly to the enzyme extract in a beaker until it became $70 \%$ saturation. The pellet holding major peroxidase activity was suspended in $0.1 \mathrm{M}$ sodium phosphate buffer ( $\mathrm{pH}$ 6.5) and the enzyme activity and protein content were determined.

\section{Dialysis}

The supernatant was discarded and precipitated extract was transferred in a dialysis bag suspended in a beaker containing ice pack and 0.01 M sodium phosphate buffer ( $\mathrm{pH}$ 6.5) and kept for $48 \mathrm{~h}$. The buffer was continuously stirred, changed after every $12 \mathrm{~h}$ and the total volume of the dialysed protein was measured and recorded. The enzyme activity and protein contents of the dialyzed extract was determined at $460 \mathrm{~nm}$ using o-dianisidine, as substrate and $750 \mathrm{~nm}$ for protein determination using bovine serum albumin (BSA) respectively. The dialyzed protein was further purified using Sephadex G-75 by column chromatography.

\section{Gel Filtration}

Ten gram of Sephadex G-75 was soaked in $0.1 \mathrm{M}$ sodium phosphate buffer ( $\mathrm{pH}$ 6.5) for $12 \mathrm{~h}$. The prepared gel was gently poured in a standing column tube $(50 \mathrm{~cm}$ by
$2.5 \mathrm{~cm})$. The packed gel was equilibrated with $0.1 \mathrm{M}$ sodium phosphate buffer solution $(\mathrm{pH} 6.5)$ and $30 \mathrm{~mL}$ of the enzyme solution was introduced into the column. A total of 70 fractions were collected in $5 \mathrm{~mL}$ fraction tubes at a flow rate of $5 \mathrm{~mL}$ per $20 \mathrm{~min}$. The protein concentration of each fraction was determined using a spectrophotometer at wavelength of $280 \mathrm{~nm}$. Peroxidase activity of each fraction was also assayed using the spectrophotometer at $460 \mathrm{~nm}$. The active fractions were pooled and stored at $-4^{\circ} \mathrm{C}$.

\section{Characterization of the Peroxidase}

The enzyme characterization was done via determination of optimum parameters below according to the method of Eze et al. (2010).

\section{Determination of Optimum $\mathrm{pH}$}

The activity of peroxidase was assayed at various $\mathrm{pH}$ ranging between 4.0 and 9.0 for $24 \mathrm{~h}$ at $35^{\circ} \mathrm{C}$ using the following buffers: Sodium-acetate buffer $(0.1 \mathrm{M}, \mathrm{pH} 4-$ 5.5); sodium phosphate buffer (0.1 M, pH 6.0-7.5) and Tris- $\mathrm{HCl}$ buffer $(0.1 \mathrm{M}, \mathrm{pH} 8-9.0)$. The residual activity was then determined using o-dianisidine as the reducing substrate for the assay.

\section{Determination of Optimal Temperature}

The optimum temperature was determined by incubating the enzyme at its optimal $\mathrm{pH}$ at various temperatures ranging from 30 to $70^{\circ} \mathrm{C}$ in a water bath. Thereafter, the residual activity of the partially purified peroxidase was determined after incubating the enzyme at the various temperature ranges for $4 \mathrm{~h}$ in phosphate buffer at 6.0. After heat treatment, the enzyme solution was cooled and the residual activity assayed under standard assay conditions.

\section{Determination of Kinetic Parameters}

The Michaelis-Menten kinetic parameters $\mathrm{Km}$ and Vmax were determined by measuring the peroxidase activity using various concentrations of O-dianisidine complex as substrate in the presence of hydrogen peroxide and a suitable amount of purified enzyme. They were mixed and incubated to determine the effect of the substrate. The parameter values were obtained by curve fitting of the reciprocal plot of reaction rates versus substrate concentrations using the Line-weaver bulk plot transformation of Michealis-Menten rate equation.

\section{Stabilization Studies of the Purified Enzyme}

The purified extract was incubated with various concentrations (0.01-0.05 M) of each divalent metal ions $\left(\mathrm{Ca}^{2+}, \mathrm{Mg}^{2+}, \mathrm{CO}^{2+}\right.$ and $\left.\mathrm{Pb}^{2+}\right)$ according to the method of Singh et al. (2012). At varying time interval, an aliquot was drawn from the incubated sample and assayed for residual activity as follows:

$$
\% \text { Residual activity } \frac{A t}{A o} \times 100
$$


where, $A t$ is activity at present while $A o$ is activity at time 0 . The $\%$ residual activity was plotted against different time interval of incubation.

\section{Statistical Analysis}

The average values of duplicate experiments were taken. The results were presented in tables and figures. Graphs were plotted using Microsoft excel worksheet 2010 model.

\section{Results}

\section{Microbial Isolation and Identification}

The soil samples from the crude oil polluted soil had heterotrophic and hydrocarbon utilizing fungi with $\mathrm{CFU} / \mathrm{g}$ of $6.9 \times 10^{8}$ and $1.15 \times 10^{7}$ while that of the uncontaminated soil (control) was $2.58 \times 10^{8}$ and $5.5 \times 10^{2}$ respectively. The polluted site also had the highest percentage of heterotrophs that are hydrocarbon utilizing. A total of four fungi isolates, belonging to three fungal families were identified. They included Saccharomyces, Penicillium, Rhizopus and Aspergillus species.

\section{Production of Peroxidase from the Isolates}

The organisms of interest, Rhizopus and Saccharomyces spp. tested positive for the peroxidase production with a distinct yellow coloration in the presence of the standard substrate O-dianisidine. A 14 day co-cultures of Rhizopus and Saccharomyces spp. showed a rise in the peroxidase activity with a peak on day 8 after which there was a decrease till day 14 as shown in Fig. 1.

\section{Purification of the Crude Peroxidase}

The crude peroxidase enzyme precipitated efficiently when $70 \%$ of the ammonium sulphate salt was used. The precipitated pellet showed the greatest peroxidase activity compared to the supernatant which precipitated when $20 \%$ ammonium sulphate was used (Fig. 2). Further purification by size exclusion gel chromatography using Sephadex G-75 (Fig. 3) showed that the specific activity $(\mathrm{U} / \mathrm{mg})$ of peroxidase and protein concentration were high between fractions 20-28 and 40-45. Fractions 25 and 45 which showed the greatest peroxidase activity were used for the characterization studies. Peroxidase activity increased sequentially in each of the three purification methods (size exclusion chromatography > dialysis > ammonium sulphate precipitation).

\section{Characterization of the Purified Enzyme}

\section{Optimum $\mathrm{pH}$}

Peroxidase was active over a broad $\mathrm{pH}$ range of 3.58.0 with an optimum activity at $\mathrm{pH} 4.5$ as shown in Fig. 4. However, the control showed maximum activity at $\mathrm{pH}$ 6.2. More so, the peroxidase was relatively stable at a $\mathrm{pH}$ range between 4.0 and 5.5 as the enzyme residual activity remained high between 65 and $76 \%$ at this $\mathrm{pH}$ range (4.0-4.5) after $180 \mathrm{~min}$ of pre-incubation of the enzyme at various $\mathrm{pH}$. The enzyme activity decreased at higher $\mathrm{pH}$. The optimum $\mathrm{pH}$ for the test sample was used for the stability studies.

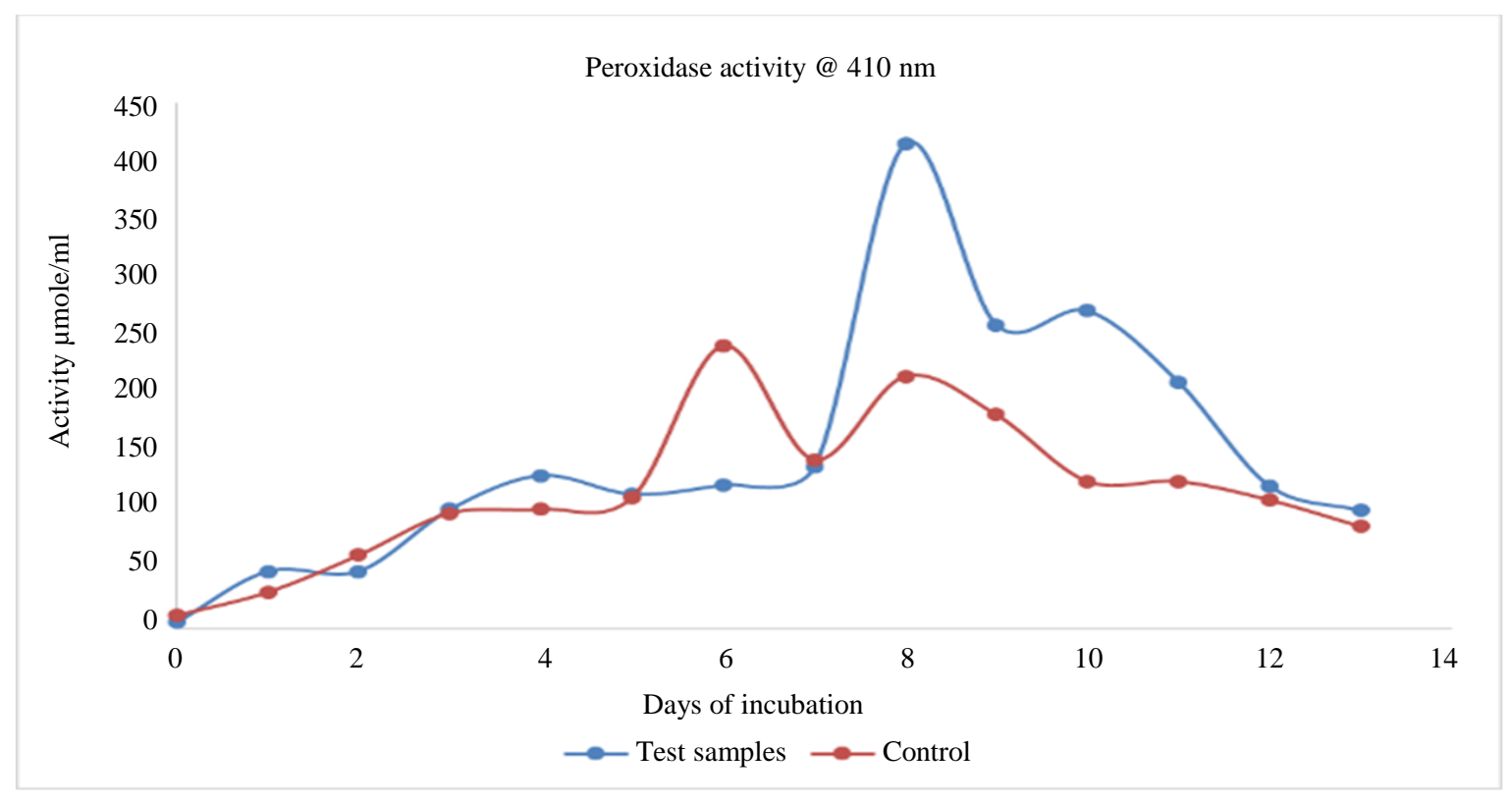

Fig. 1: Effect of incubation days on the enzyme activity of the peroxidase produced from the di-cultures of Saccharomyces sp. and Rhizopus sp 


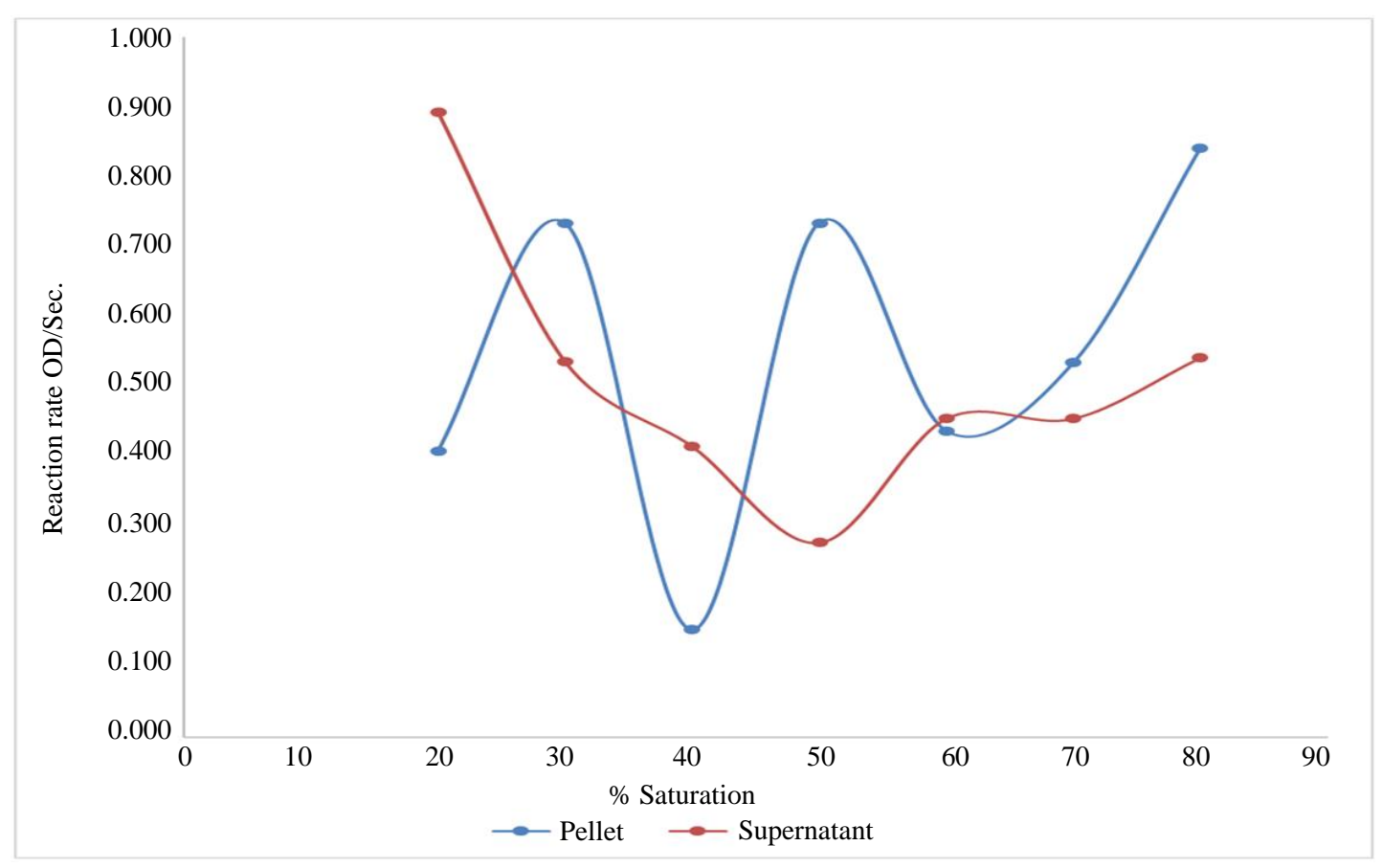

Fig. 2: Ammonium sulphate precipitation profile of the peroxidase produced from the di-culture of Rhizopus sp. and Saccharomyces $\mathrm{sp}$.

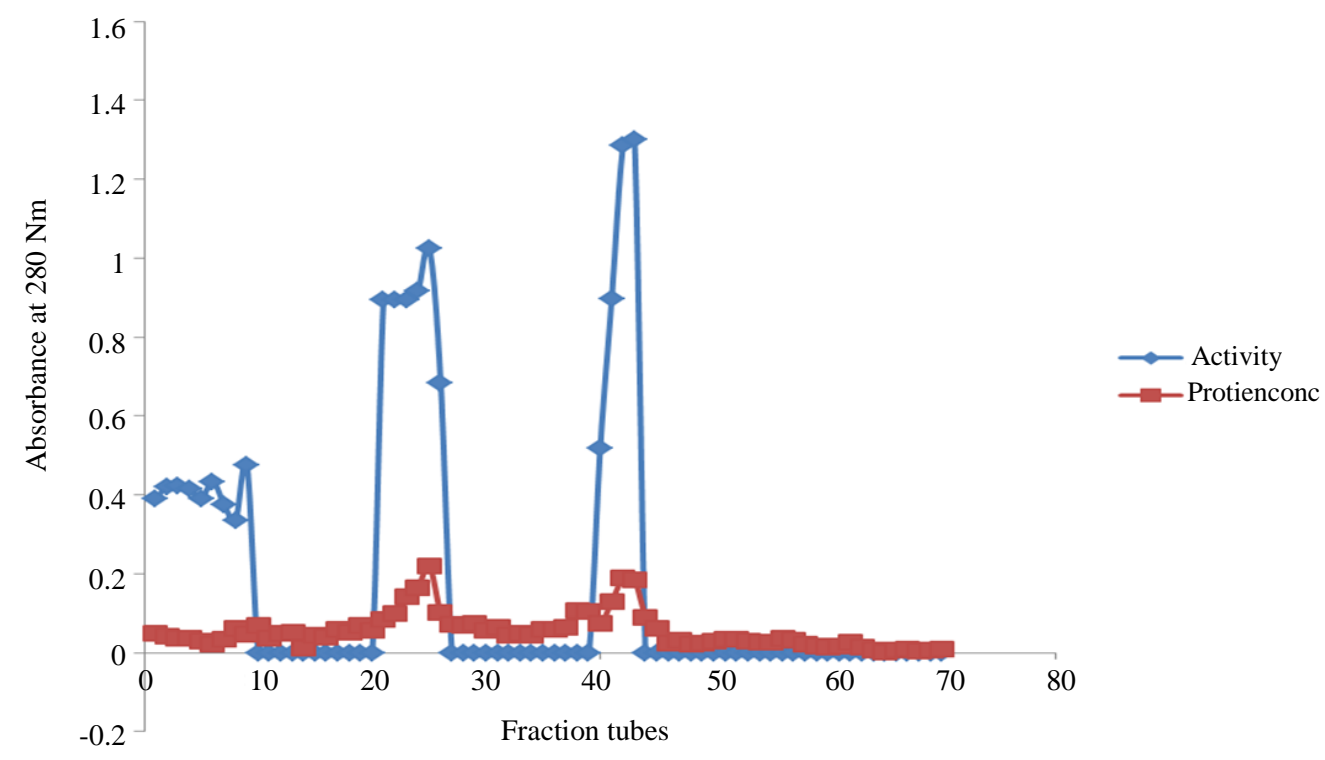

Fig. 3: Gel elution profile of the protein extracts produced from the di-culture of Rhizopus sp. and Saccharomyces sp

\section{Optimum Temperature}

Thermo-stability analysis revealed that peroxidase had maximum stability at temperature of $60^{\circ} \mathrm{C}$ as $58 \%$ activity was retained after $180 \mathrm{~min}$ of pre-incubation at this temperature as shown in Fig. 5. The enzyme activity examined at different temperatures showed an optimum activity at $50^{\circ} \mathrm{C}$ while the control showed optimum activity at $40^{\circ} \mathrm{C}$. The result illustrated in Fig 5 showed an increase in peroxidase activity with the increase in temperature and reached the maximum at $50^{\circ} \mathrm{C}$, then it began to decline with increasing temperature until reached about $40 \%$ of its activity at $70^{\circ} \mathrm{C}$ for the test sample. The enzyme activity began to decline after the optimum temperature. The optimum temperature for the test sample was used for the stability study. 


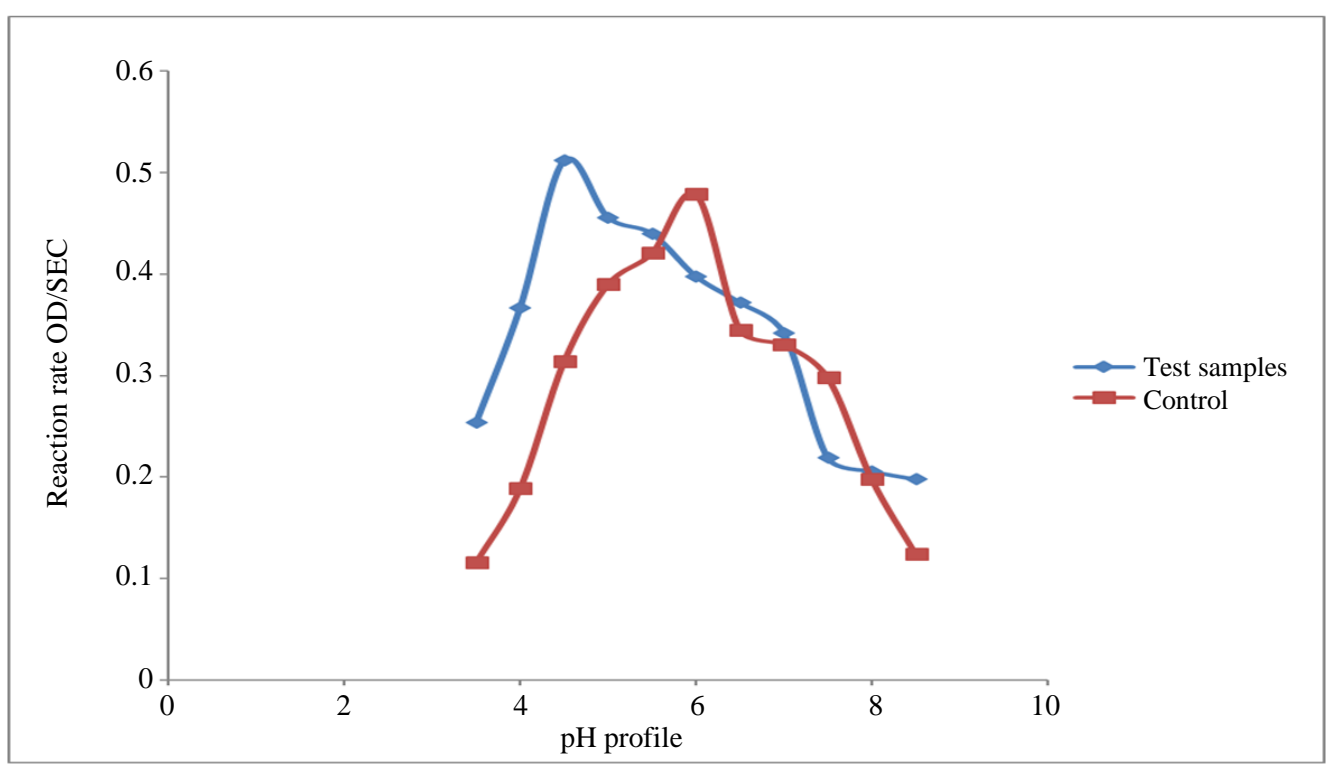

Fig. 4: Effect of pH profile on the activity of the peroxidase produced from the di-culture of Rhizopus sp. and Saccharomyces sp

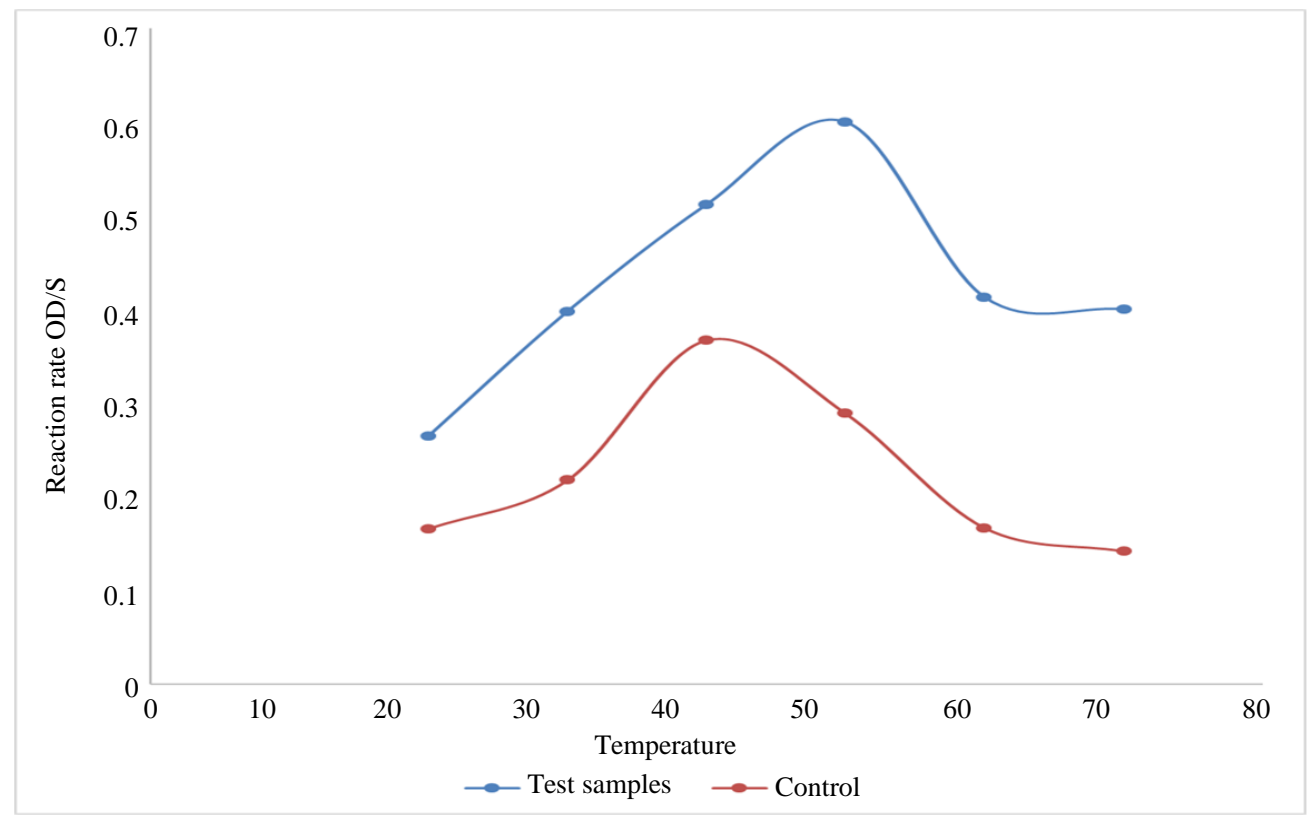

Fig. 5: Effect of varying temperature ranges on the activity of the peroxidase produced from the di-culture of Rhizopus and Saccharomyces $\mathrm{sp}$

\section{Enzyme Kinetic Parameters}

The activity of peroxidase increased with corresponding increase in substrate concentration until a saturation point of $5 \mathrm{mM}$ for the O-dianisidine as shown in a Michaelis-Menten curve in Fig. 6. A LineweaverBulk plot of the initial velocity using o-dianisidine substrate in Fig. 7 showed the peroxidase to have a $\mathrm{Km}$ of $1.8 \mathrm{mM}$ and $V \max$ of $20 \mu / \mathrm{ml} / \mathrm{min}$.

\section{Stability Studies on the Purified Enzyme Extract}

Stability study at $\mathrm{pH} 4.5$ showed $\mathrm{CaCl}_{2}, \mathrm{MgSO}_{4}$ and $\mathrm{CoCl}_{2}$ to stabilize the enzyme activity of peroxidase. $\mathrm{CaCl}_{2}$ showed the best stability of the enzyme as up to $90-95 \%$ of the enzyme activity was retained at $0.02 \mathrm{M}$ $\mathrm{CaCl}_{2}$ at $\mathrm{pH} 5.0-5.5$ while $78-88 \%$ of the activity was retained at $\mathrm{pH} 3.5-4.5$. The stabilization in activity 
increased with increase in the concentration of the metal salts with $0.05 \mathrm{M}$ concentrations of $\mathrm{CaCl}_{2}$ conferring the highest stability. Other metal ions $\left(\mathrm{MgSO}_{4}\right.$ and $\left.\mathrm{CoCl}_{2}\right)$ followed the same trend. Alternatively, $\mathrm{Pb}^{2+}$ at all concentrations inhibited the enzyme activity of peroxidase as the enzyme lost about $83-95 \%$ of its activity with $\mathrm{PbCl}_{2}$ at concentrations of $0.02-0.03 \mathrm{M}$ (Fig. 8). Also at $50^{\circ} \mathrm{C}$, the peroxidase activity was greatest when $\mathrm{CaCl}_{2}$ was used. Thus, $\mathrm{CaCl}_{2}$ showed the greatest stability of the enzyme activity at $50^{\circ} \mathrm{C}$ (Fig. 9).

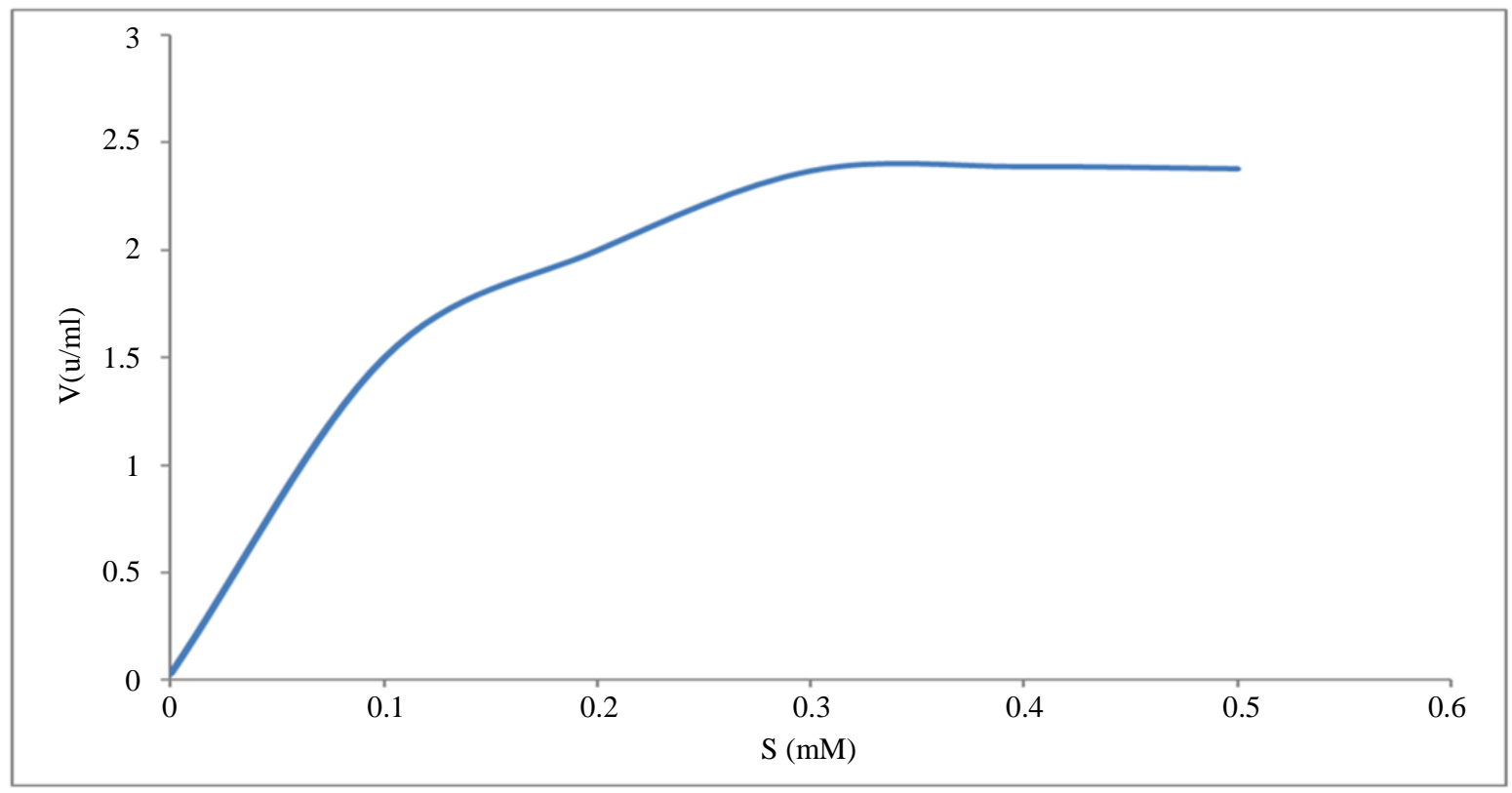

Fig. 6: Michaelis-Menten curve on the effect of o-dianisidine on the activity of the peroxidase produced from the di-culture of Rhizopus and Saccharomyces spp

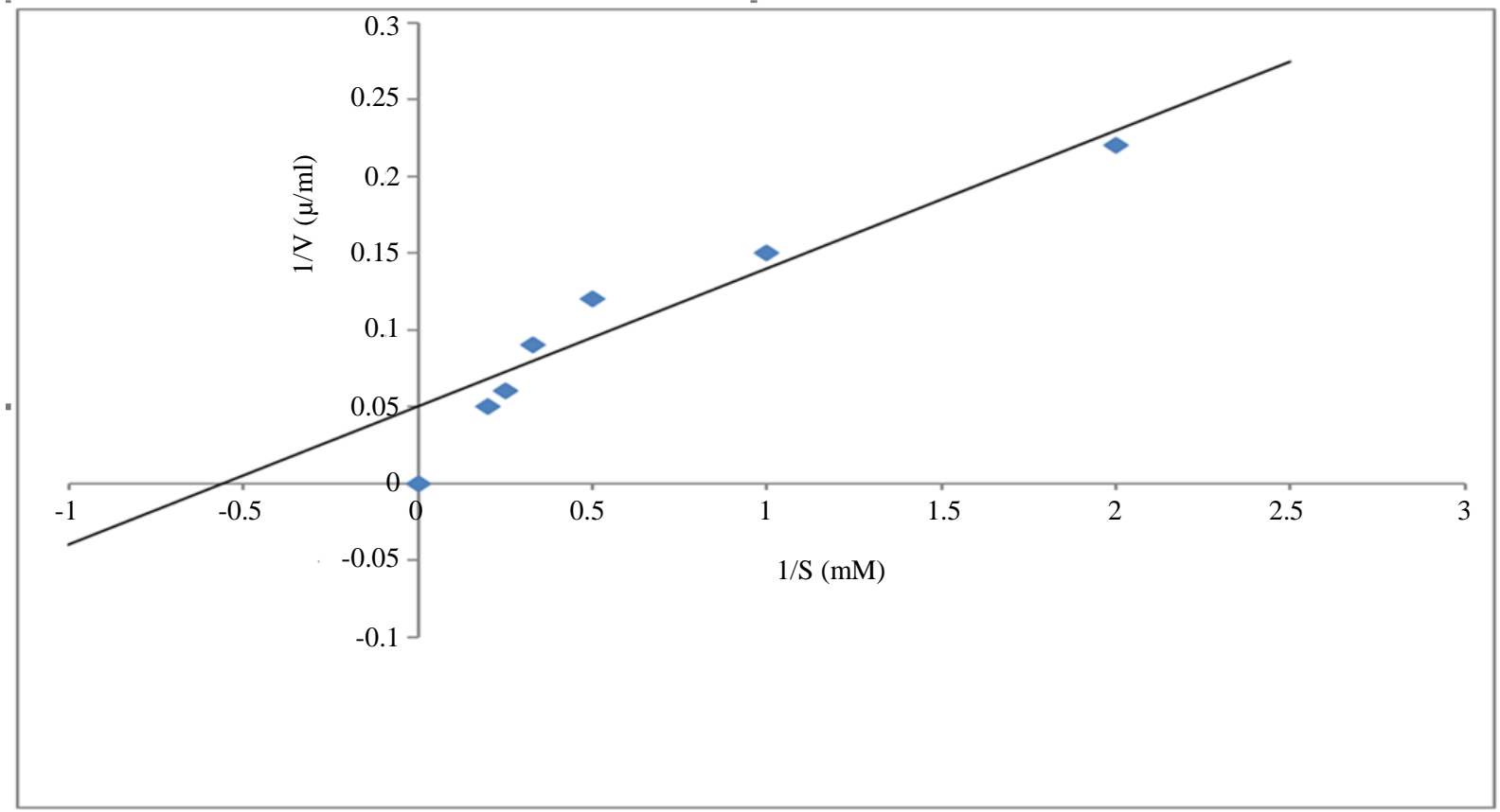

Fig. 7: Lineweaver-burke double reciprocal curve on the effect of o-dianisidine on the activity of the peroxidase produced from the di-culture of Rhizopus and Saccharomyces spp 


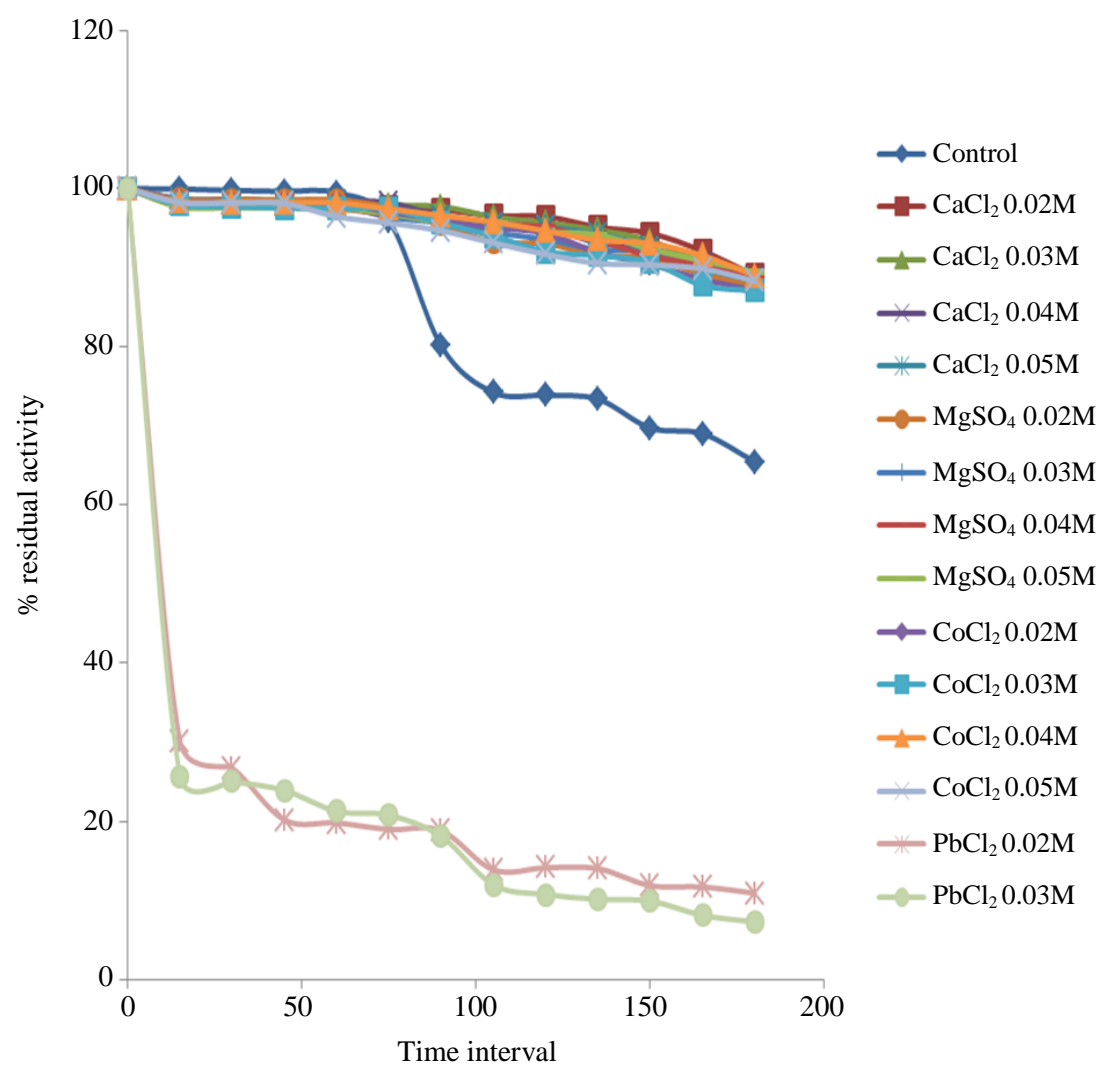

Fig. 8: $\mathrm{pH} 4.5$ stability study on the activity of the peroxidase produced from the di-culture of Rhizopus and Saccharomyces sp. incubated for $180 \mathrm{~min}$

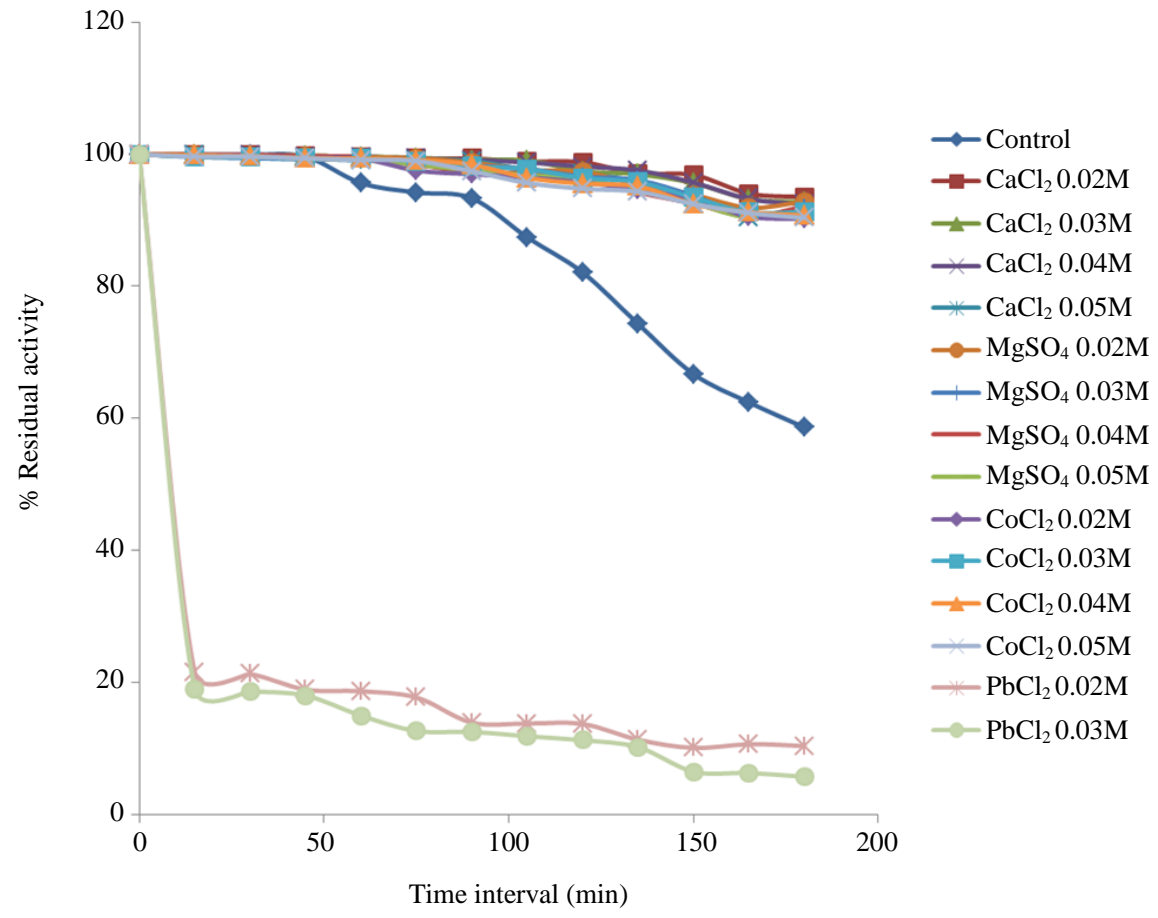

Fig. 9: Temperature $50^{\circ} \mathrm{C}$ stability study on peroxidase produced from the di-culture of Rhizopus sp. and Saccharomyces sp. incubated for $180 \mathrm{~min}$ 


\section{Discussion}

Fungus is considered as an efficient candidate for potential degradation of hydrocarbons. Hundreds of different species of fungi inhabit the soil, especially near the soil surface where aerobic conditions prevail. Such fungi are active in degrading a wide variety of biological materials present in the soil (Saranraj and Stella, 2013). In this study, crude oil polluted soil contained heterotrophic and hydrocarbon utilizing fungi. This finding suggests that the polluted site may be actively receiving hydrocarbons which in turn increased microbial population. This study concurs with that of Chikere and Azubuike (2014) which showed high level of heterotrophic fungi count than hydrocarbon utilizing fungi confirming that the site was chronically polluted with hydrocarbons. Four fungi isolates which included Saccharomyces, Penicillium, Rhizopus and Aspergillus species were isolated. Previous studies have confirmed the presence of these fungi species in crude oil populated soil (Rahman et al., 2002; Brooijmans et al., 2009; Balaji et al., 2013).

Peroxidase activity was confirmed in Rhizopus and Saccharomyces spp. cultures which showed a characteristic yellow coloration in the presence of the standard substrate, O-dianisidine. Crude enzyme was produced from the fungal di-culture and the enzyme activity was greatest at day 8 of the incubation period. The crude enzyme was partially purified with $70 \%$ saturation of ammonium sulphate which led to increased activity of the enzyme. Similar result was observed by Idesa and Getachew (2018) who reported $80 \%$ saturation of Ammonium sulphate precipitation of peroxidase from plant sources. However, this result is comparable to the report of Hamid et al. (2016) whose peroxidase extracted from wheat bran showed that peroxidase was precipitated efficiently with ammonium sulfate in saturation ratio of $70 \%$. Upon dialysis of the precipitated enzyme, unwanted salt and proteins were removed. Following further purification by gel filtration, the enzyme activity increased at each purification step. This is also similar to the findings of Hamid et al. (2016) who reported a purification fold of 2.4, 3.4 and 5.1 with specific activities of $730 \mathrm{U} / \mathrm{ml}$ on a three-purification step using ammonium sulphate precipitation, ion exchange chromatography and gel filtration chromatography.

Characterization and stabilization of purified enzymes under controlled optimum condition $(\mathrm{pH}$ and temperature) are key physiological factors to be considered for maximum enzyme activity and for applications in industries and the environment (Singh et al., 2014). The partially purified peroxidase showed a maximum activity at $\mathrm{pH} 4.5$ and was relatively stable in the $\mathrm{pH}$ range between 4.0 and 5.5. This result is similar to that of Osuji et al. (2014) which showed peroxidase extracted from garlic to have an optimum $\mathrm{pH}$ of 5.0 with the highest percentage decolorization of dye at $\mathrm{pH} 4.5$ and was stable at $\mathrm{pH}$ between 4.0 and 6.0. Also, another study by Bhatti et al. (2012) has shown peroxidase from Raphanus sativus to have an optimum activity at $\mathrm{pH} 4.0$. The findings from this study agrees with findings of Pinto et al. (2015) who observed a broad range of $\mathrm{pH} 4.5$ up to 7.5 for umbu peroxidase and its activity maintained at $70 \%$ levels. The $\mathrm{pH}$ curve also showed a bell-like shape distribution suggesting an involvement of two amino acid residues in catalysis as reported by Pinto et al. (2015).

Peroxidase when examined at different temperature ranges showed maximum activity at $50^{\circ} \mathrm{C}$. The thermostability of the peroxidase dropped significantly at $70^{\circ} \mathrm{C}$ suggesting that temperature above that range can lead to denaturation and inactivation of the enzyme. Hamid et al. (2016) observed the same trend of optimum temperature for peroxidase activity purified from wheat bran, which showed an increase in peroxidase activity with the increase in temperature. This is comparable with the report of Osuji et al. (2014) and Bhatti et al. (2012) which reported peroxidase to have an optimum activity at $55^{\circ} \mathrm{C}$. Chilaka et al. (2010) and Eze et al. (2010) reported a thermostable peroxidase from an oil bean plant with optimal temperature of $70^{\circ} \mathrm{C}$. Nwagu and Okolo (2011) reported an optimum temperature of $70^{\circ} \mathrm{C}, 55^{\circ} \mathrm{C}$ and $50^{\circ} \mathrm{C}$ respectively for peroxidase from Candida, Mucor and Aspergillus respectively. Dayanand et al. (2011) reported an optimum temperature of $40^{\circ} \mathrm{C}$ and optimum $\mathrm{pH}$ of 3.0 in bacterial peroxidase isolated from strain of Pseudomonas sp. SUK1.

The effect of the substrate concentration on the peroxidase activity increased with increase in substrate concentration until a saturation point of $5 \mathrm{mM}$ for $\mathrm{O}$ dianisidine indicating that the active sites were saturated with the substrate. The $\mathrm{Km}(1.8 \mathrm{mM})$ for this study was similar to that of Kim and Lee (2005) who reported Km value of $1.18 \mathrm{mM}$ for $\mathrm{o}$-dianisidine and $1.27 \mathrm{mM}$ for hydrogen peroxide. However, the $V \max (20 \mathrm{u} / \mathrm{ml} / \mathrm{min})$ was greater as compared to that of Kim and Lee with $V \max 0.032 \mathrm{u} / \mathrm{ml} / \mathrm{min}$ for o-dianisidine and 0.138 $\mathrm{u} / \mathrm{ml} / \mathrm{min}$ for hydrogen peroxide, for peroxidase from Raphanus sativus. Pinto et al. (2015) reported that peroxidases oxidize several different substrates in the presence of hydrogen peroxide. Peroxidase showed high affinity and catalytic efficiency towards the $\mathrm{O}$ dianisidine substrate.

The stability studies showed $\mathrm{CaCl}_{2}$ to best stabilize the enzyme. Adefila et al. (2012) reported similarly in their work that $\mathrm{Ca}^{2+}$ and $\mathrm{Mn}^{2+}$ were potent activators of $\alpha$ amylase. Pinto et al. (2015) reported a stimulatory effect of $\mathrm{Ca}^{2+}$ on peroxidase present in Xilopodium exsudates of umbu plants, with $\mathrm{Mg}^{2+}$ having similar effect but at a lower concentration than that of $\mathrm{Ca}^{2+}$, whereas $\mathrm{Mn}^{2+}$ displayed inhibitory effect. However, $\mathrm{Pb}^{2+}$ inhibited the 
activity of the enzyme. Singh et al. (2014) have also reported an inhibitory effect by $\mathrm{Hg}^{2+}, \mathrm{Pb}^{2+}$ and $\mathrm{Cu}^{2+}$ and attributed this inhibition by these ions on the enzyme activity to the presence of indole amino acids in the enzyme and also a reflection of competition between exogenous and protein associated cations. In the presence of $\mathrm{CaCl}_{2}$, the enzyme retained up to $87-89 \%$ activity at temperature range $30^{\circ} \mathrm{C}-40^{\circ} \mathrm{C}$ and $90-93 \%$ activity at temperature range of $50^{\circ} \mathrm{C}-60^{\circ} \mathrm{C}$ and $89-90 \%$ at $70^{\circ} \mathrm{C}$. It was observed that the activity of the enzyme increased as the metal ions concentrations increased in all metal salts. $\mathrm{MgSO}_{4}$ showed a promising strength in thermo-stability of the enzyme while $\mathrm{CoCl}_{2}$ followed suit. In the presence of $\mathrm{Pb}^{2+}$, the enzyme lost $90-95 \%$ activity in all the temperature ranges. These findings is in accordance with that of Adefila et al. (2012) and Singh et al. (2014) respectively which stated that $\mathrm{Pb}^{2+}$ and other heavy metals $\left(\mathrm{Cu}^{2+}, \mathrm{Hg}^{2+}\right.$ and $\left.\mathrm{Zn}^{2+}\right)$ are like poison to enzymes and thus can inhibit their activity. These results confirms that the effect of metal ions on peroxidase activity is highly variable over enzymes from different sources.

\section{Conclusion}

This finding showed that an appreciable amount of peroxidase was produced and partially purified from a di-culture of Rhizopus and Saccharomyces spp. isolated from crude oil polluted soil. The characteristics of peroxidase produced was able to show activity over a wide range of $\mathrm{pH}(3.5-8.0)$ and temperature $\left(20^{\circ} \mathrm{C}\right.$ $70^{\circ} \mathrm{C}$ ) with optimum activity at $\mathrm{pH} 4.5$ and temperature $50^{\circ} \mathrm{C}$ and was best stabilized by $\mathrm{CaCl}_{2}$. Therefore, the peroxidase exhibit high thermostable properties and has proven to be an environmentally stable enzyme which can be employed as a molecular tool for biotechnological process. Peroxidases among other vital biotechnological applications are useful tools in environmental monitoring. They are relatively cheaper to produce and do not require much augmentation and biostimulation in the presence of recalcitrant. Therefore peroxidase from the di-culture of Rhizopus and Saccharomyces spp. can be produced on large scale for industrial and eco toxicological relevance. The three-step purification and stability process indicates its strong capability for bioremediation processes. However, further studies are necessary to ascertain its effectiveness in the biodegradation of hydrocarbon contents in a petroleum polluted soil.

\section{Acknowledgement}

The authors are grateful to Mr. Ezidi Cletus and other staff of Bio-resources Development Centre, Abagana for their support.

\section{Funding Information}

This work was solely funded by Ferdinand U. Paschaline.

\section{Author's Contributions}

Ferdinand U. Paschaline: Conceived and designed the experiments, performed the experiment and processed the data, analyzed the data and wrote the manuscript.

Onyeocha O. Ignatius: Supervised the research, analyzed the data, interpreted the data and revised the manuscript.

Ezeji E. Uchechukwu: Co-supervised the research and revised the manuscript.

Ukwandu C. D. Nnamdi: Analyzed the research design and methodology, interpreted the data.

Engwa A. Godwill: Co-supervised and revised the manuscript.

Oparaji E. Henry: Guided the experimental design, performed the experiment and processed the data.

\section{Ethics}

Authors declared no ethical issues that may arise after the publication of this manuscript.

\section{References}

Adefila, O., M. Bakare and O. Adewale, 2012. Characterization of $\alpha$-amylase from sorghum (sorghum bicolor) obtained under optimized conditions. J. Institute Brew., 118: 6369.

DOI: $10.1002 /$ jib.11

Al-Sayegh, A., Y. Al-Wahaibi1, J. Sanket, S. Al-Bahry and A. Elshafie et al., 2016. Bioremediation of heavy crude oil contamination. Open Biotechnol. J., 10: 301-311. DOI: 10.2174/1874070701610010301

Balaji, V., P. Arulazhagen and P. Ebenezer 2013. Enzymatic bioremediation of polyaromatic hydrocarbon byfungal consortia enriched from petroleum contaminated soil and oil seeds. J. Environ. Biol., 35: 0254-8704.

Barnett, H. and B. Hunter, 1972. Illustrated Genera of Imperfect Fungi. 1st Edn., Macmillan Publishing Company, New York.

Bhatti, H.N., U. Kalsoom and A. Habib, 2012. Decolorization of direct dyes using peroxidase from Raphanus sativus (FO4 SL). J. Chem. Soc. Pak., 34: 257-262.

Brooijmans, R., M. Pastink and R. Siezen, 2009. Hydrocarbon-degrading bacteria: The oil spill cleanup crew. Microbiol. Biotechnol., 2: 587-594.

DOI: $10.1111 /$ j.1751-7915.2009.00151.x 
Cappuccino, J.G. and N. Sherman, 2004. Microbiology: A Laboratory Manual. 7th Edn., Pearson Education (Singapore), Indian Branch, New Delhi, ISBN-10: 080532836X, pp: 544.

Chandrakant, S.K. and S.R. Shwetha, 2011. Role of microbial enzymes in the bioremediation of pollutants: A review. Enzyme Res.

DOI: $10.4061 / 2011 / 805187$

Chikere, C. and C.C. Azubuike, 2014. Characterization of hydrocarbon utilizing fungi from hydrocarbon polluted sediments and water. Nigerian J. Biotechnol., 27: 49-54

Chilaka, F., S. Eze and B.C. Nwanguma, 2010. Studies on thermodynamics and kinetics of thermo-inactivation of some quality-related enzyme in white yam (Dioscorea rotundata). J. Thermodynamic Catalysis, 1: 104-104.

DOI: 10.4172/2157/-7544.1000104

Dayanand, C.K., S.K. Swapnil, U.S. Utkarsha and P.J. Jyoti, 2011. Bacterial peroxidase isolated from strain of pseudomonas sp. Annals Microbiol., 61: 483-491.

Draelos, Z.D., 2015. A split-face evaluation of a novel pigment-lightening agent compared with no treatment and hydroquinone. J. Am. Acad. Dermatol., 72: 105-107.

DOI: $10.1016 /$ j.jaad.2015.02.1133

Ehiosun, K.I. and M. Usman, 2018. Evaluation of crude oil bioremediation efficiency and peroxidase production by Streptomyces albus. J. Applied Sci. Environ. Manage., 22: 213-217.

DOI: $10.4314 /$ jasem.v22i2.10

Ertan, H., K.S. Siddiqui, J. Muenchhoff, T. Charlton and R. Cavicchioli, 2012. Kinetic and thermodynamic characterization of the functional properties of a hybrid versatile peroxidase using isothermal titration calorimetry: Insight into manganese peroxidase activation and lignin peroxidase inhibition. Biochimie, 94: 1221-1231.

DOI: 10.1016/j.biochi.2012.02.012

Eze, S., F. Chilaka and B. Nwanguma, 2010. Studies on thermodynamics and kinetics of thermo-inactivation of some quality-related enzyme in white yam (Dioscore rotundata). J. Thermodynamic Catalysis, 1: 104-104. DOI: 10.4172/2157-7544.1000104

Ezeonu, M., J. Okafor and J. Ogbonna, 2013. Laboratory Exercises in Microbiology. 1st Edn., Ephrata Publishing and Printing Company, Nsukka.

Feltrin, A.C., S.O. Garcia, S.S. Caldas, E.G. Primel and E.B Adiale-Furlong et al., 2017a. Characterization and application of the Enzyme mycotoxin Deoxynivalenol (DON). J. Environ. Sci. Health Part B, 52: 777-783.

DOI: $10.1080 / 03601234.2017 .1356672$
Feltrin, A.C., V.M. Ramos, G.H. Delgado, E.B. AdialeFurlong and J. Garda-Buffon, 2017b. Peroxidasefrom soybean meal: Obtention, purification and application in the reduction of dioxynivalenol levels. Quimica Nova, 40: 45-50. DOI: 10.21577/0100-4042.20170088

Hamid, M., H. Majeed and A. Al-Assie, 2016. Purification and characterization of peroxidase extracted from wheat bran. World J. Pharmaceut. Res., 5: 77-86.

Idesa, G.D. and B. Getachew, 2018. Extraction and partial purification of peroxidase enzyme from plant sources for antibody labelling. Int. J. Vet. Sci. Technol.,3:006-012.

Kim, S.S. and D.J. Lee, 2005. Purification and characterization of a cationic peroxidase $\mathrm{Cc}$ in Raphanus sativanus. J. Plant Physiol., 162: 609-617. DOI: 10.1016/j.jplph.2004.10.004

Krainer, F.W. and A. Glieder, 2015. An updated view on horseradish peroxidases: Recombinant production and biotechnological applications. Applied Microbiol. Biotechnol., 99: 1611-1625. DOI: $10.1007 / \mathrm{s} 00253-014-6346-7$

Lowry, H.O., N.J. Rosebrough, A.L. Farr and R.J. Randall, 1951. Protein measurement with the Folin phenol reagent. J. Biol. Chem., 193: 265-275. PMID: 14907713

McLellan, K.M. and D.S. Robinson, 1987. Purification and heat stability of brussel sprout peroxidase isoenzymes. Food Chem., 23: 305-319. DOI: 10.1016/0308-8146 (87)90116-6

Nair, I.C. and K. Jaayachandran, 2017. Enzymes for Bioremediation and Biocontrol. In: Bioresources and Bioprocess in Biotechnology, Sugathan, S., N. Pradeep and S. Abdulhameed (Eds.), Springer, Singapore, ISBN-10: 978-981-10-4282-9, pp: 75-97.

Neelam, B. and S.K. Shamsher, 2013. Peroxidase (s) in environment protection Review article. Scientific World J., 2013: 1-9. DOI: 10.1155/2013/714639

Nwagu, T. and N. Okolo, 2011. Extracellular amylase production of a thermo tolerant fusarium species isolated from eastern Nigerian soil. Brazilian Archive Biol. Technol., 54: 1516-8913.

DOI: $10.1590 / \mathrm{S} 1516-89132011000400002$

Osuji, A.C., S.O. Eze, E.E. Osayi and F.C. Chilaka, 2014. Bio-bleaching of industrial important dyes with peroxidase partially purified from garlic. Scientific World J., 2014: 1-8. DOI: $10.1155 / 2014 / 183163$

Pinto, M.T., J.M. Ribeiro, F.P. Araúj, N.F. Melo and S.K. Fernandes, 2015. Purification and characterization of a peroxidase present in xilopodium exsudates of umbu plants (Spondias tuberosa A.). African J. Biotechnol., 14: 1838-1845.

DOI: $10.5897 / A J B 2015.14521$ 
Ferdinand U. Paschaline et al. / American Journal of Biochemistry and Biotechnology 2019, 15 (4): 218.229 DOI: 10.3844/ajbbsp.2019.218.229

Rahman, K.S., J. Thahira-Rahman, P. Lakshmanaperumalsamy and I.M. Banat, 2002. Towards efficient crude oil degradation by a mixed bacterial consortium. Bio. Resource Technol., 83: 257-261. DOI: 10.1016/S0960-8524(02)00119-0

Saranraj, P. and D. Stella, 2013. Fungal amylase-a review. Int. J. Microbiol. Res., 4: 203-211. DOI: 10.5829/idos.ijmr.2013.4.2.75170

Singh, R., V. Kumar and V. Kapoor, 2014. Partial purification and characterization of a heat stable $\alpha$ amylase from a thermophilic actinobacteria, Streptomyces sp. MSC702. Enzyme Res., 2014: 1-8. DOI: $10.1155 / 2014 / 106363$
Taboada-Puig, R., T.A. Lu-Chau, G. Eibes, G. Feijoo and M.T. Moreira et al., 2015. Continuous removal of endocrine disruptors by versatile peroxidase using a two-stage system. Biotechnol. Procedures, 31: 908-916. DOI: $10.1002 /$ btpr.2116 